\title{
Association between physical activity and vitamin D: A narrative literature review
}

\author{
Marcos Rassi Fernandes ${ }^{1 *}$, Waldivino dos Reis Barreto Junior ${ }^{2}$ \\ ${ }^{1} \mathrm{PhD}$ in Health Sciences, Lecturer Advisor of the Graduate Program in Health Sciences, Faculdade de Medicina da Universidade Federal de Goiás (FM-UFG), Goiânia, GO, Brazil \\ ${ }^{2}$ MSc. Student of the Graduate Program in Health Sciences, FM-UFG, Goiânia, GO, Brazil
}

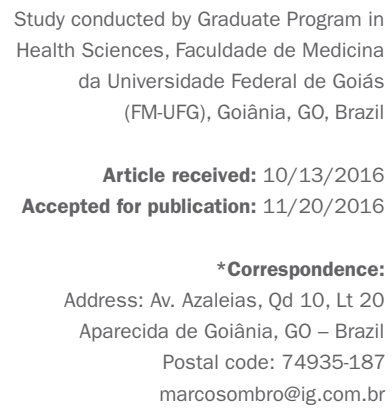

http://dx.doi.org/10.1590/1806-9282.63.06.550

\section{SUMMARY}

This narrative review of the medical literature assessed whether outdoor and indoor physical activity would increase the plasma levels of vitamin D. Synthesis of this liposoluble vitamin is mainly mediated by sunlight on the skin, where it is activated to perform its main action, which is to control the serum levels of calcium as soon as the element is absorbed in the intestines, assisting in the regulation of bone metabolism. Physical activity is any body movement that results in energy expenditure, while outdoor physical activity refers to physical activity carried out at public parks or other open spaces, as is the case of the popular practice of taking walks. Exercising outdoors would have both the benefits of physical activity and of sun exposure, namely the synthesis of vitamin D. However, according to the studies analyzed, increased plasma concentration of vitamin D occurs with physical activity both indoors and outdoors.

Keywords: vitamin D, physical activity, environmental exposure, sunlight, external work environment.

\section{INTRODUCTION}

Vitamin D is a liposoluble compound with antioxidant properties, essential for maintaining the body's mineral balance. It can be acquired from an exogenous source (feed) or endogenously synthesized from the incidence of the sun's ultraviolet rays on the skin. Although it is a vitamin, it is also considered a hormone, since its activation is made by means of chemical reactions inside the organism. ${ }^{1}$

Vitamin D occurs in the form of two biologically inert precursors or prohormones, vitamin D2 (ergocalciferol) and vitamin D3 (cholecalciferol). Ergocalciferol is of vegetable origin, whereas cholecalciferol is of animal origin, being formed by ultraviolet $\mathrm{B}$ radiation on 7-dehydrocholesterol. ${ }^{2}$ Vitamin D in these forms must be converted into active hormone to be able to exert biological influence on mineral metabolism and other physiological functions. ${ }^{1}$

Physical activity is any movement of the body produced by skeletal muscles that results in greater energy expenditure than that of rest levels. Performing physical activity in an outdoor environment, with sun exposure, would provide benefits both from the physical work itself and from vitamin D synthesis and action in the body. ${ }^{3}$ Based on current evidence, our narrative review of the literature aimed to answer whether physical activity performed both outdoors (with sun exposure) and indoors (without sun exposure) would increase vitamin D plasma levels.

\section{Historical ASPECTS}

Elmer V. McCollum at the end of the $19^{\text {th }}$ century, in experiments on fats associated with the cure of certain diseases (rickets), observed how this process took place in the organism and its relation in the interruption of inadequate bone mineralization during growth due to lack of sun exposure. Today, this substance is called vitamin D. ${ }^{4}$

Physical activity has always existed throughout history, both indoors (Figure 1) and outdoors ${ }^{5}$ (Figure 2). Millennial accounts of Greeks, Chinese and Indians in relation to the practice of physical activity affirm the idea that a stimulated body becomes strong regardless of variation in the environment. The important thing is for the individual to become an adept of this practice. ${ }^{6,7}$ 


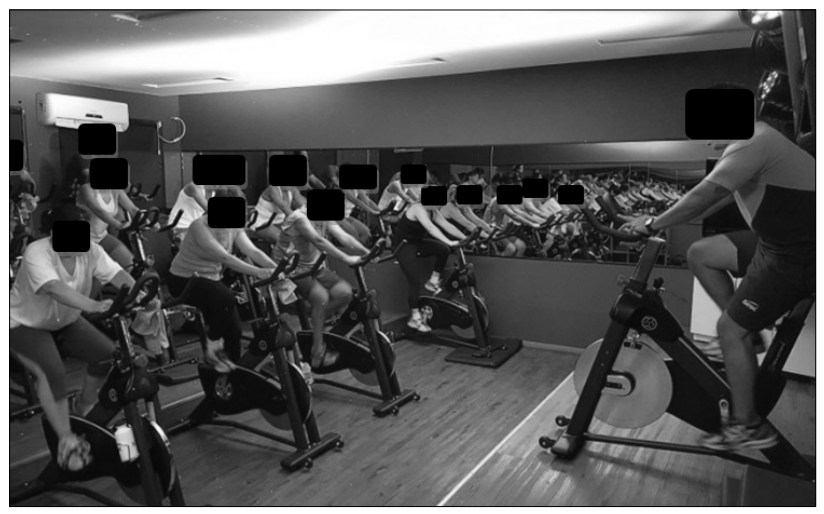

FIGURE 1 Indoor physical activity.

\section{Vitamin D}

The needs of the human body, in relation to vitamin $\mathrm{D}$, are supplied to a lesser extent by the exogenous absorption of dietary sources: vitamin $\mathrm{D} 2$, found in vegetables and called ergocalciferol, and vitamin D3, of animal origin, found in fish and called cholecalciferol. But most of it is endogenously synthesized. ${ }^{8}$

Both participate in the same metabolic process. These forms of vitamin $\mathrm{D}$ are produced in the epidermis by 7-dehydrocholesterol photolysis action/reaction. ${ }^{9}$ After synthesis, vitamin D remains inactive, mainly bound to a vitamin $\mathrm{D}$ binding protein and, to a lesser extent, albumin, and circulates through the bloodstream until it reaches the liver. There, it undergoes hydroxylation at carbon 25 , generating 25 -hydroxyvitamin $\mathrm{D}$ or calcidiol. It is a rapid process that undergoes little regulation, and the product is deposited in the reservoir of adipose tissue. To be active, this vitamin requires participation of the kidneys and 1-hydroxylase enzyme. Then, vitamin D3 goes back into the bloodstream to the kidneys and, mediated by the enzyme hydroxylase, forms 1,25-dihydroxyvitamin $\mathrm{D}$ or calcitriol. This renal action is controlled by several factors, unlike the previous stage, in the liver, which is poorly regulated ${ }^{10,11}$ (Figure 3 ).

Vitamin D acts in the control of plasma calcium levels, after its absorption in the intestinal tract, aiding in the regulation of bone metabolism. It also acts in noncalcemic effects, such as strengthening the immune system, improving balance and preventing premature aging. ${ }^{4}$

Researchers' interest in vitamin $\mathrm{D}$ has been enhanced by recent advances related to biology, as it plays an important role far beyond calcium metabolism in various extraskeletal tissues such as adipocytes, skeletal striated muscle, and pancreatic tissue. It also participates in the modulation of immunity and inflammation, which shows its therapeutic potential in diseases such as multiple sclerosis, type 1

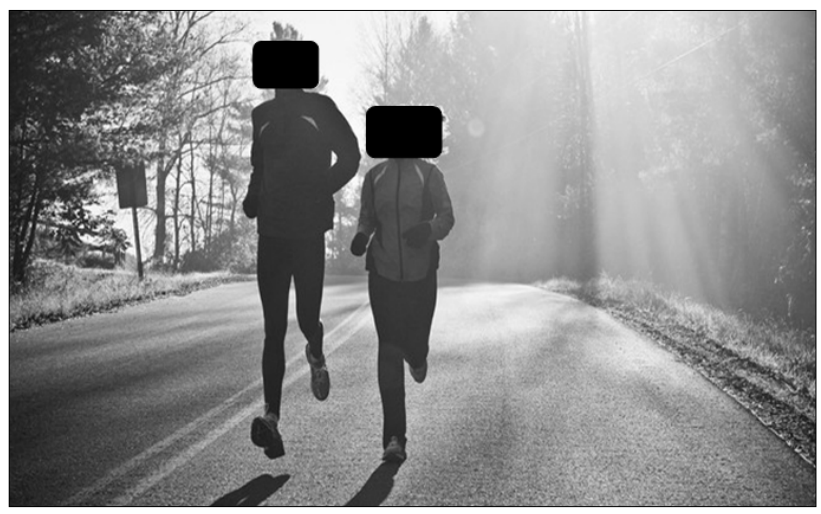

FIGURE 2 Outdoor physical activity.

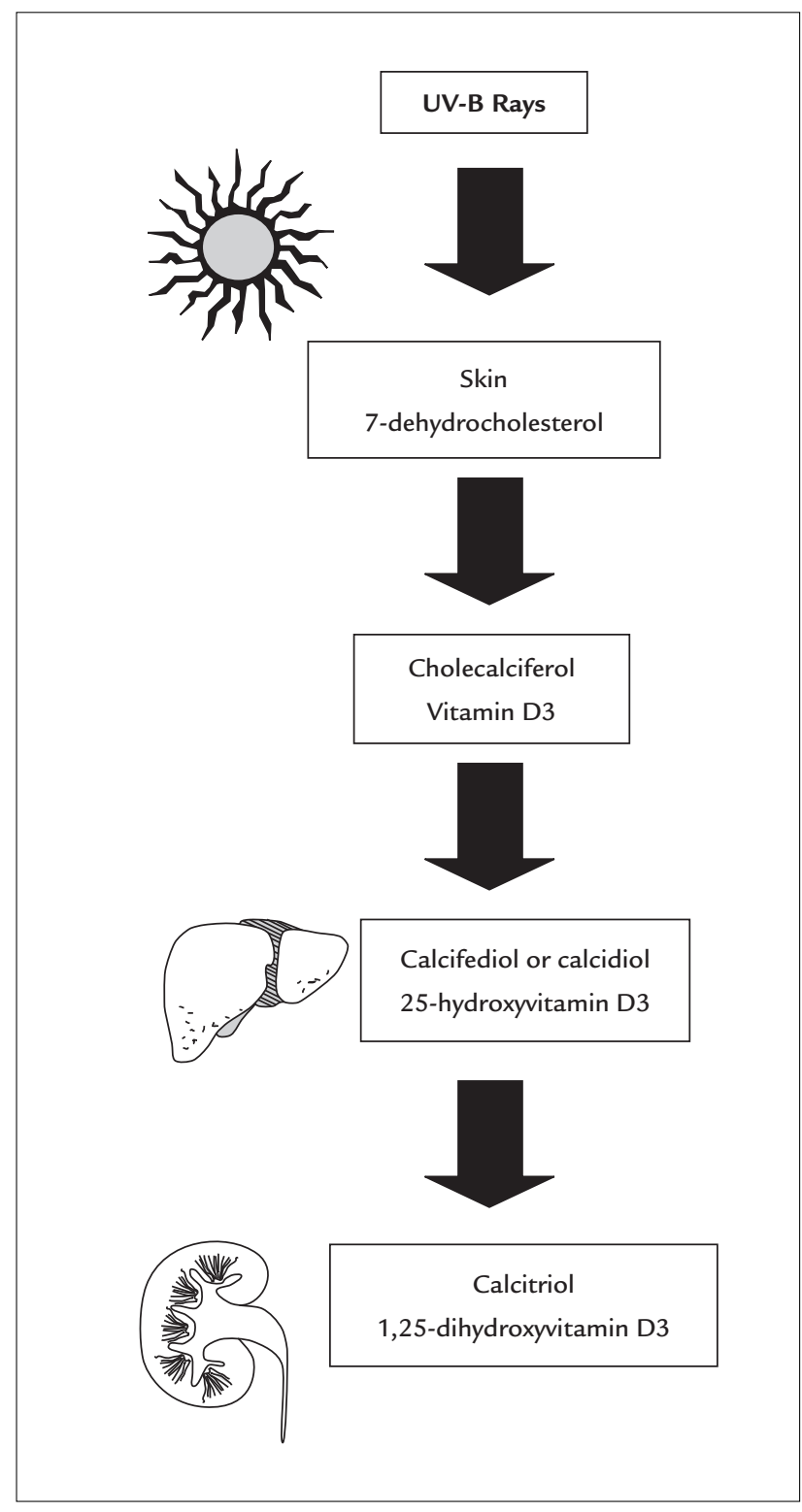

FIGURE 3 Scheme of vitamin D formation. 
and 2 diabetes, and autoimmune dermatological and thyroid diseases. Obesity has a negative correlation with plasma vitamin D levels, and vitamin D deficiency causes an increased risk for the development of metabolic syndrome, as well as increased oxidative burden. ${ }^{4}$

\section{Physical activity}

Although physical activity is thought to be synonymous with physical exercise, it is actually any movement caused by a muscle contraction resulting in increased energy expenditure than at rest. ${ }^{3}$ Physical exercise is defined as well-structured, planned and repetitive physical activity, aiming at improving health, well-being, and maintaining physical fitness. ${ }^{12}$ The purpose of their use is what sets them apart. Physical activity is therapeutic and its purpose is treatment, while physical exercise improves physical fitness. ${ }^{13,14}$

Physical fitness, in turn, is defined by the amount of energy that a person has while performing physical work, according to physical valences, and involves flexibility, strength, endurance and motor coordination. ${ }^{15}$ From a physical point of view, an inactive individual is one who does not practice physical activity for at least 150 minutes per week. ${ }^{16}$

There is a type of exercise called green, which is given to activity practiced in nature, with behavioral results in stress relief in acute exercise sessions. ${ }^{17}$

Outdoor physical activity would be its accomplishment in squares, parks and field environments. ${ }^{18}$ The most popular of these activities is walking, practiced by the elderly with the goal of improving health and preventing diseases. ${ }^{19}$

Studies show that some cities joined the creation of outdoor fitness centers, with the incorporation and adaptation of gymnastics and bodybuilding equipment, with a view to physical, mental and social improvement ${ }^{20}$ (Figure 4).

\section{Association between physical activity and VITAMIN D}

Regular practice of physical activity has several benefits to the human being, but it is regulated by innumerable demographic, social, physical, environmental, economic and psychological factors that can be both stimulating and inhibiting. ${ }^{21}$

Vitamin D, important in the absorption of calcium at the intestinal level, also acts in the immune, cardiovascular and musculoskeletal systems. Solar exposure in outdoor environment allows the synthesis of this vitamin, with a consequent process of gain of bone tissue through its mineralization. According to current knowledge, the skin is the only organ capable of producing vitamin D, which is also absorbed from dietary intake. ${ }^{22}$

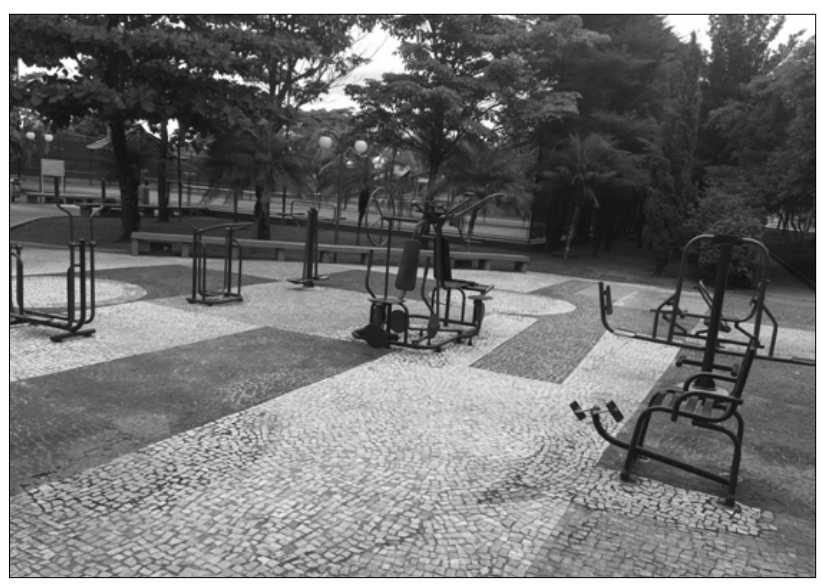

FIGURE 4 Outdoor fitness Center.

There is research indicating the practice of physical activity in outdoor settings, but they do not mention the importance of vitamin D. ${ }^{17,23}$ Similarly, there are studies on the synthesis of vitamin $\mathrm{D}$ from the incidence of sun rays on the skin, but they do not mention physical activity with sun exposure. ${ }^{24}$ Why not consider outdoor physical activity in view of the benefits of such activity along with the possibility of vitamin D synthesis from skin exposure to ultraviolet $\mathrm{B}$ ? It is important to establish if this type of activity, in outdoor environment, would be the only one capable of increasing vitamin D plasma levels (Figure 2).

Sela and Sela identified the beneficial results of outdoor sports, with elderly individuals having better disposition for this activity, as well as less depression, and a reduction in body weight and medication intake, favoring their quality of life. ${ }^{25} \mathrm{~A}$ systematic review by Mochcovitch et al. also demonstrated that regular physical activity may be effective for the improvement of anxiety symptoms in older adults; however, they concluded that more research would be necessary to identify the modality, frequency, duration and intensity to optimize the positive effects of this activity on anxiety in the study population. ${ }^{26}$ The authors did not mention physical activity with sun exposure for vitamin D synthesis, as seen in the study by Al-Eisa et al., who reported the improvement of the individual's physical performance associated with vitamin $\mathrm{D}$ and calcium levels as factors to prevent muscle fatigue. ${ }^{27}$

Vitamin D sufficiency related to physical activity provides better neuromuscular performance, including with increased type II muscle fibers, and also improves the regulatory role of the immune system. Indoor environments, more pigmented skin and excessive use of sports equipment favor vitamin $\mathrm{D}$ deficiency. ${ }^{28}$ 
Pagels et al. compared indoor and outdoor physical activity among 179 children aged 7 to 14 years from schools in Sweden, and found that outdoor physical activity led to a moderate and vigorous increase in physical activity, during all seasons of the year. ${ }^{22}$ This strong correlation between the variables of moderate/vigorous physical activity and outdoor environment was also found in the studies by Sallis et al. ${ }^{29}$ and Cooper et al. ${ }^{30}$ These authors did not, however, study the association with serum levels of vitamin D. ${ }^{22,29,30}$

Pagels et al., in another recent study, report that outdoor environment, due to suberythemal exposure to the sun even at high latitudes, has a favorable health impact, helping students to acquire vitamin D. ${ }^{31}$ Therefore, moderate exposure to ultraviolet rays in outdoor environment during school days in northern European countries has a positive impact on the immune system, bone mineralization and, possibly, mental health. ${ }^{22}$

Florez et al. conducted a cross-sectional study and found an association between vitamin D levels, body mass index and outdoor physical activity in white Hispanic, and non-Hispanic patients. In Hispanics, there was a high prevalence of hypovitaminosis $\mathrm{D}$ among the obese compared to non-obese individuals. The practice of outdoor physical activity decreased the prevalence of hypovitaminosis $\mathrm{D}$, with individuals $47 \%$ less likely to have this condition. ${ }^{32}$

Valtueña et al. investigated 408 Spanish athletes from 34 different modalities, both male and female, and concluded that $82 \%$ had suboptimal levels of plasma vitamin $\mathrm{D}$ concentration, demonstrating that outdoor physical training is the appropriate way to increase this concentration in athletes. ${ }^{33}$

Some studies, however, mention high levels of physical activity associated with increases in vitamin D levels in older adults over the years, regardless of outdoor practice. This, because indoor physical practice would also result in increased levels of vitamin $\mathrm{D}$, suggesting that the concentration of vitamin $\mathrm{D}$ is not only attributed to high sun exposure..$^{34-37}$

The findings of the analysis based on data from the US National Health and Nutrition Examination Survey (NHANES) indicate that physical activity is associated with high serum levels of vitamin $\mathrm{D}$, regardless of indoor or outdoor practice..$^{38}$ Scragg and Camargo conducted an earlier study using the same database (NHANES III), and found that the association between physical activity and vitamin $\mathrm{D}$ was stronger in outdoor compared with indoor environments. ${ }^{39}$ Therefore, even though both studies have reported associations between physical activity and vita- min $\mathrm{D}$ in older individuals, and despite the fact that the ability of vitamin $\mathrm{D}$ synthesis from sun exposure decreases with age, the results were not replicated. ${ }^{38,39}$

Independent effects on sun exposure during physical activity may be associated with increased plasma concentrations of vitamin D. A French study by Touvier et al. supports this claim, with findings of association between physical activity and vitamin $\mathrm{D}$ after adjusting for sun exposure and outdoor sports. ${ }^{40}$ Maimoun and Sultan also corroborate the hypothesis that other factors, which are known and altered by physical activity, may contribute to elevated levels of vitamin D metabolites in athletes, such as decreased serum phosphate and ionized calcium..$^{41,42}$

In addition, Kimlin et al., in an Australian study, reported that exposure to ultraviolet rays was responsible for only $8 \%$ of the variation found in vitamin $\mathrm{D}$ concentration, while the largest contribution was clothing coverage (27\%), followed by location (20\%), season (17\%), supplementation (7\%) and body mass index/physical activity, with $4 \%$ each. These results suggest that modifiable factors related to sun exposure could help maintain the healthy state of vitamin $\mathrm{D}$, such as decreased clothing coverage, rather than increasing the duration of exposure to ultraviolet rays. ${ }^{43}$

Van den Heuvel et al. evaluated the contribution of different physical activity characteristics, such as duration, intensity and location, in relation to plasma levels of vitamin D and concluded that physical activity performed at high intensity had the strongest positive association with vitamin D levels. ${ }^{44}$

It is important to emphasize that exposure of the body to the sun during physical activity should have some particularities in order to raise the plasma concentrations of vitamin $\mathrm{D}$, since it depends on the amount of melanin present in the skin, the type of clothing and the use of sunscreen, as well as hour of the day, season of the year, latitude of the place and age of the individual. ${ }^{28,45,46}$

The studies included in our narrative review are presented in Table 1 (outdoor physical activity and vitamin D synthesis) and Table 2 (indoor physical activity and vitamin $\mathrm{D}$ synthesis), and show sample size, study design and their main findings.

Directed attention plays a fundamental role in cognitive functions, but once it is weakened, the individual's ability to concentrate for certain tasks is reduced, leading to mental fatigue. ${ }^{47}$ The practice of physical activity interacting with nature may be important for recovery of this directed attention, which is closely linked to the process of regaining balance. ${ }^{48-51}$ 
TABLE 1 Summary of studies in the narrative review: Outdoor physical activity and synthesis of vitamin D.

\begin{tabular}{|c|c|c|c|c|}
\hline Studies & Year & Sample & Study design & Main findings \\
\hline Pagels et al. ${ }^{31}$ & 2016 & 196 & Cross-sectional & Suberythemal exposure to the sun contributed to the synthesis of vitamin D \\
\hline Florez et al. ${ }^{32}$ & 2007 & 291 & Cross-sectional & $\begin{array}{l}\text { The practice of outdoor physical activity decreased the prevalence of } \\
\text { hypovitaminosis D }\end{array}$ \\
\hline Valtueña et al. ${ }^{33}$ & 2014 & 408 & Cross-sectional & $\begin{array}{l}\text { Outdoor physical training is the appropriate way to increase the plasma } \\
\text { concentration of vitamin D in athletes }\end{array}$ \\
\hline Scragg and Camargo ${ }^{39}$ & 2008 & 15,148 & Cross-sectional & $\begin{array}{l}\text { The association between physical activity and vitamin } D \text { was stronger outdoors } \\
\text { compared to indoor environments }\end{array}$ \\
\hline
\end{tabular}

TABLE 2 Summary of studies in the narrative review: Indoor physical activity and synthesis of vitamin D.

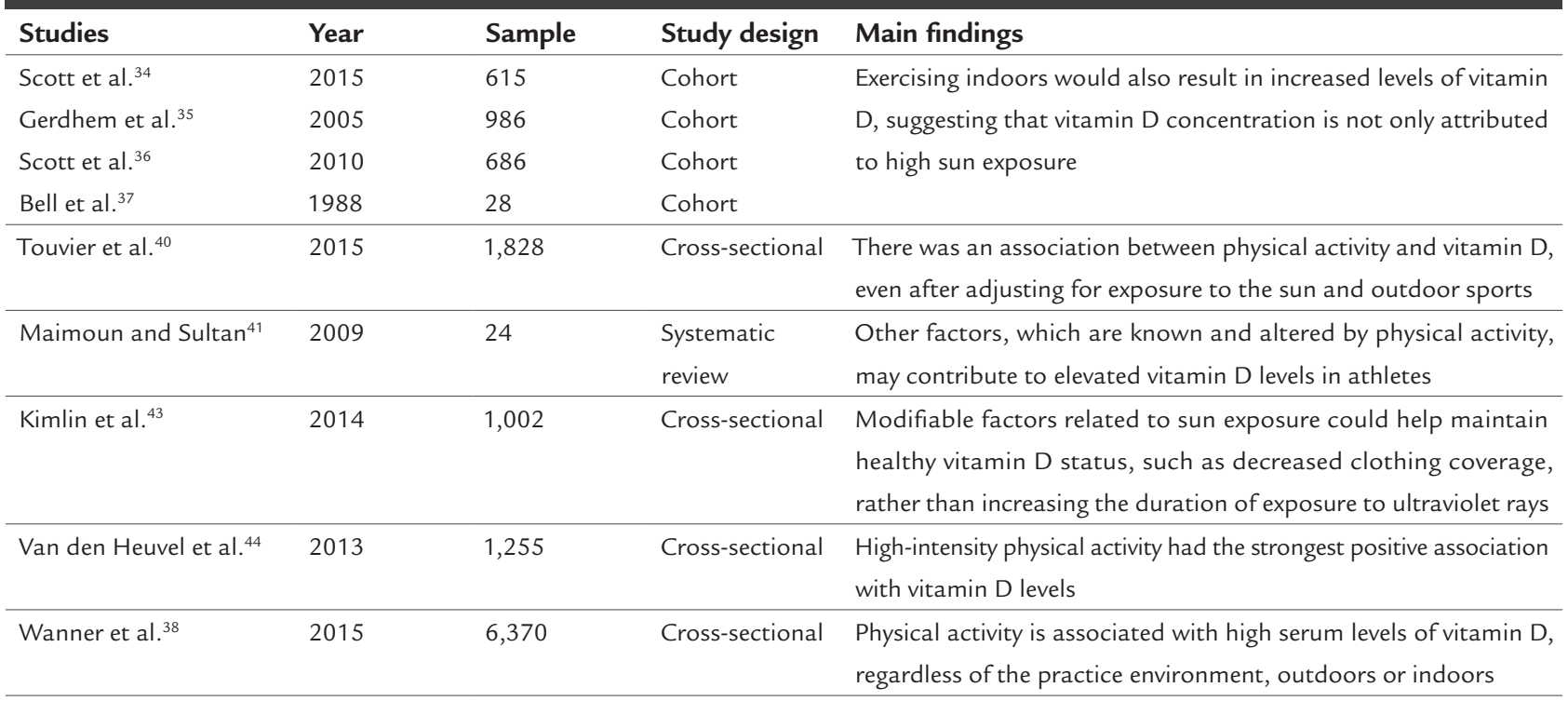

The sufficiency of vitamin $\mathrm{D}$ has been related to the mental health of the individuals due to the presence of receptors of this vitamin in cells inside the brain, ${ }^{52-54}$ also favoring their cognitive performance..$^{55,56} 25(\mathrm{OH}) \mathrm{D}$, in a cross-sectional analysis, was associated with the cognitive decline of subjects over 65 years. ${ }^{57}$ Therefore, both the practice of physical activity and the status of vitamin $\mathrm{D}$ are relevant to the reduction of common mental illnesses. ${ }^{52-58}$

\section{Conclusion}

According to the studies included in our narrative review, there is an elevation of the plasma concentration of vitamin D both with physical activity indoors and outdoors. However, randomized controlled trials are needed to compare the synthesis of vitamin D (serum level) associated with physical activity in both settings, so that the difference between the groups would be the incidence or absence of sunlight alone.

\section{Resumo}

Associação entre atividade física e vitamina D: revisão narrativa da literatura

Esta revisão narrativa da literatura avaliou se tanto a atividade física realizada ao ar livre quanto aquela em ambiente interno aumentariam os níveis plasmáticos da vitamina $\mathrm{D}$. A síntese dessa vitamina lipossolúvel ocorre, principalmente, por meio da radiação solar na pele, que, após sofrer processo de ativação no organismo, estabelece sua principal ação no controle dos níveis séricos do cálcio, assim que é absorvido no trato intestinal, auxiliando na regulação do metabolismo ósseo. Atividade física é qualquer movimento corporal que resulte em gasto energético, enquanto atividade física ao ar livre é aquela realizada em parques ou praças, cuja prática mais popular é a caminhada. Esse ambiente externo teria os benefícios propriamente ditos da atividade física, além da exposição solar com a 
síntese da vitamina D. Entretanto, segundo os estudos apresentados, há elevação da concentração plasmática da vitamina $\mathrm{D}$ na realização de atividade física tanto em ambiente interno quanto ao ar livre.

\section{Palavras-chave: vitamina $\mathrm{D}$, atividade física, exposição} ambiental, luz solar, ambiente externo de trabalho.

\section{References}

1. Inda Filho AJ, Melamed ML. Vitamina D e doença renal: o que nós sabemos e o que nós não sabemos. J Bras Nefrol. 2013; 35(4):323-31.

2. Kich DM, Vieira FAS, Bassuino M, Linden R. Determinação de 25-hidroxivitamina D2 e D3 em plasma por CLAE-DAD. J Bras Patol Med Lab. 2012; 48(5):329-36.

3. Bjørgen K. Physical activity in light of affordances in outdoor environments: qualitative observation studies of 3-5 years old in kindergarten. Springerplus. 2016; 5(1):950

4. Caprio M, Infante M, Calanchini M, Mammi C, Fabbri A. Vitamin D: not just the bone. Evidence for beneficial pleiotropic extraskeletal effects. Eat Weight Disord. 2017; 22(1):27-41.

5. Antunes HKM, Santos RF, Cassilhas R, Santos RVT, Bueno OFA, Mello MT. Exercício físico e função cognitiva: uma revisão. Rev Bras Med Esporte. 2006; 12(2):108-14.

6. Nahas MV, Garcia LMT. Um pouco de história, desenvolvimentos recentes e perspectivas para a pesquisa em atividade física e saúde no Brasil. Rev Bras Educ Fis Esporte. 2010; 24(1):135-48.

7. Araújo DSMS, Araújo CGS. Aptidão física, saúde e qualidade de vida relacionada à saúde em adultos. Rev Bras Med Esporte. 2000; 6(5):194-203.

8. Premaor MO, Furlanetto TW. Hipovitaminose D em adultos: entendendo melhor a apresentação de uma velha doença. Arq Bras Endocrinol Metab. 2006; 50(1):25-37

9. Barral D, Barros AC, Araújo RPC. Vitamina D: uma abordagem molecular. Pesq Bras Odontoped Clin Integr. 2007; 7(3):309-15.

10. Pedrosa MAC, Castro ML. Papel da vitamina D na função neuro-muscular. Arq Bras Endocrinol Metab. 2005; 49(4):495-502

11. Marques CDL, Dantas AT, Fragoso TS, Duarte ALBP. A importância dos níveis de vitamina D nas doenças autoimunes. Rev Bras Reumatol. 2010; 50(1):73-80.

12. Thomaz PMD, Costa THM, Silva EF, Hallal PC. Fatores associados à atividade física em adultos, Brasília, DF. Rev Saúde Pública. 2010; 44(5):894-900.

13. Matsudo SM, Matsudo VKR, Barros Neto TL. Atividade física e envelhecimento: aspectos epidemiológicos. Rev Bras Med Esporte. 2001; 7(1):2-13.

14. Ribeiro RR, Santos KD, Carvalho WRG, Gonçalves EM, Roman EP, Minatto G. Aerobic fitness and biological and sociodemographic indicators in female school children. Rev Bras Cineantropom Desempenho Hum. 2013; 15(4):448-57

15. Campos ALP, Del Ponte LS, Cavalli AS, Afonso MR, Schild JFG, Reichert FF. Efeitos do treinamento concorrente sobre aspectos da saúde de idosas. Rev Bras Cineantropom Desemp Hum. 2013; 15(4):437-47.

16. Alves $C$, Lima RVB. Impacto da atividade física e esportes sobre o crescimento e puberdade de crianças e adolescentes. Rev Paul Pediatr. 2008; 26(4):383-91.

17. Rogerson M, Gladwell VF, Gallagher DJ, Barton JL. Influences of green outdoors versus indoors environmental settings on psychological and social outcomes of controlled exercise. Int J Environ Res Public Health. 2016; 13(4):363.

18. Silva DAS, Petroski EL, Reis RS. Barreiras e facilitadores de atividades físicas em frequentadores de parques públicos. Motriz Rev Educ Fis. 2009; 15(2):219-27.

19. Ory MG, Towne Jr SD, Won J, Forjuoh SN, Lee C. Social and environmental predictors of walking among older adults. BMC Geriatr. 2016; 16(1):155.

20. Martins LS, Ovando RGM. Benefícios dos exercícios resistidos ao ar livre para terceira idade de Campo Grande. Rev Cient JOPEF. 2012; 13(1):27-35.

21. Jesus GM, Jesus EFA. Nível de atividade física e barreiras percebidas para a prática de atividades físicas entre policiais militares. Rev Bras Ciênc Esporte. 2012; 34(2):433-48.
22. Pagels P, Raustorp A, Guban P, Fröberg A, Boldemann C. Compulsory school in- and outdoors-implications for school children's physical activity and health during one academic year. Int J Environ Res Public Health. 2016; 13(7):699.

23. Ceci R, Hassmén P. Self-monitored exercise at three different RPE intensities in treadmill vs field running. Med Sci Sports Exerc. 1991; 23(6):732-8.

24. Wintermeyer E, Ihle C, Ehnert S, Stöckle U, Ochs G, De Zwart P, et al. Crucial role of vitamin D in the musculoskeletal system. Nutrients. 2016; 8(6):319

25. Sela VM, Sela FER. A academia da terceira idade como um projeto do governo municipal de Maringá-PR para solucionar as falhas de mercado. Caderno Administração. 2012; 20(1):82-90.

26. Mochcovitch MD, Deslandes AC, Freire RC, Garcia RF, Nardi AE. The effects of regular physical activity on anxiety symptoms in healthy older adults: a systematic review. Rev Bras Psiquiatr. 2016; 38(3):255-61.

27. Al-Eisa ES, Alghadir AH, Gabr SA. Correlation between vitamin D levels and muscle fatigue risk factors based on physical activity in healthy older adults. Clin Interv Aging. 2016; 11:513-22.

28. Borges N, Teixeira VH. Vitamina D’atleta. Rev Med Desp. 2011; 2(4):6-8

29. Sallis JF, Prochaska JJ, Taylor WC. A review of correlates of physical activity of children and adolescents. Med Sci Sports Exerc. 2000; 32(5):963-75.

30. Cooper AR, Page AS, Wheeler BW, Hillsdon M, Griew P, Jago R. Patterns of GPS measured time outdoors after school and objective physical activity in English children: The PEACH project. Int J Behav Nutr Phys Act. 2010; 7:31.

31. Pagels P, Wester U, Soderström M, Lindelof B, Boldemann C. Suberythemal sun exposures at Swedish schools depend on sky views of the outdoor environments - Possible implications for pupils' health. Photochem Photobiol 2016; 92(1):201-7.

32. Florez H, Martinez R, Chacra W, Strickman-Stein N, Levis S. Outdoor exercise reduces the risk of hypovitaminosis D in the obese. J Steroid Biochem Mol Biol. 2007; 103(3-5):679-81

33. Valtueña J, Dominguez D, Til L, González-Gross M, Drobnic F. High prevalence of vitamin D insufficiency among elite Spanish athletes: the importance of outdoor training adaptation. Nutr Hosp. 2014; 30(1):124-31.

34. Scott D, Ebeling PR, Sanders KM, Aitken D, Winzenberg T, Jones G. Vitamin $\mathrm{D}$ and physical activity status: associations with five-year changes in body composition and muscle function in community-dwelling older adults. J Clin Endocrinol Metab. 2015; 100(2):670-8.

35. Gerdhem P, Ringsberg KAM, Obrant KJ, Akesson K. Association between 25-hydroxy vitamin D levels, physical activity, muscle strength and fractures in the prospective population-based OPRA study of elderly women. Osteoporos Int. 2005; 16(11):1425-31.

36. Scott D, Blizzard L, Fell J, Ding C, Winzenberg T, Jones G. A prospective study of the associations between 25-hydroxyvitamin D, sarcopenia progression, and physical activity in older adults. Clin Endocrinol (Oxf) 2010; 73(5)581-7.

37. Bell NH, Godsen RN, Henry DP, Shary J, Epstein S. The effects of musclebuilding exercise on vitamin D and mineral metabolism. J Bone Miner Res. 1988; 3(4):369-73.

38. Wanner M, Richard A, Martin B, Linseisen J, Rohrmann S. Associations between objective and self-reported physical activity and vitamin D serum levels in the US population. Cancer Causes Control. 2015; 26(6):881-91.

39. Scragg R, Camargo Jr CA. Frequency of leisure-time physical activity and serum 25-hydroxyvitamin D levels in the US population: results from the Third National Health and Nutrition Examination Survey. Am J Epidemiol 2008; 168(6):577-86.

40. Touvier M, Deschasaux M, Montourcy M, Sutton A, Charnaux N, KesseGuyot, et al. Determinants of vitamin D status in Caucasian adults: influence of sun exposure, dietary intake, sociodemographic, lifestyle, anthropometric, and genetic factors. J Invest Dermatol. 2015; 135(2):378-88.

41. Maimoun L, Sultan C. Effect of physical activity on calcium homeostasis and calciotropic hormones: a review. Calcif Tissue Int. 2009; 85(4):277-86.

42. Fukumoto S. Phosphate metabolism and vitamin D. Bonekey Rep. 2014; 3:497.

43. Kimlin MG, Lucas RM, Harrison SL, Van der Mei I, Armstrong BK, Whiteman DC, et al. The contributions of solar ultraviolet radiation exposure and other determinants to serum 25-hydroxyvitamin D concentrations in Australian adults: the AusD Study. Am J Epidemiol. 2014; 179(7):864-74.

44. Van den Heuvel E, Van Schoor N, De Jongh R, Visser M, Lips P. Cross sectional study on different characteristics of physical activity as determinants of vitamin D status; inadequate in half of the population. Eur J Clin Nutr. $2013 ; 67(4): 360-5$ 
45. Oliveira V, Lara GM, Lourenço ED, Boff BD, Stauder GZ. Influência da vitamina D na saúde humana. Acta Bioquím Clin Latinoam. 2014; 48(3):339-47.

46. Cargill J, Lucas RM, Gies P, King K, Swaminathan A, Allen MW, et al. Validation of brief questionnaire measures of sun exposure and skin pigmentation against detailed and objective measures including vitamin D status. Photochem Photobiol. 2013; 89(1):219-26.

47. Castro LCG. O sistema endocrinológico vitamina D. Arq Bras Endocrinol Metab. 2011; 55(8):566-75.

48. Keniger LE, Gaston KJ, Irvine KN, Fuller RA. What are the benefits of interacting with nature? Int J Environ Res Public Health. 2013; 10(3):913-35.

49. Dias CAG, Melo VA, Alves Júnior ED. Os estudos dos esportes na natureza: desafios teóricos e conceituais. Rev Port Cien Desp. 2007; 7(3):358-67.

50. Flowers EP, Freeman P, Gladwell VF. A cross-sectional study examining predictors of visit frequency to local green space and the impact this has on physical activity levels. BMC Public Health. 2016; 16:420.

51. Calogiuri G, Evensen K, Weydahl A, Andersson K, Patil G, Ihlebæk C, et al. Green exercise as a workplace intervention to reduce job stress. Results from a pilot study. Work. 2015; 53(1):99-111.

52. Garcion E, Wion-Barbot N, Montero-Menei CN, Berger F, Wion D. New clues about vitamin D functions in the nervous system. Trends Endocrinol Metab. 2012; 13(3):100-5.
53. Schäfer TK, Herrmann-Lingen C, Meyer T. Association of circulating 25-hydroxyvitamin D with mental well-being in a population-based, nationally representative sample of German adolescents. Qual Life Res. 2016; 25(12):3077-86

54. Callegari ET, Reavley N, Garland SM, Gorelik A, Wark JD. Vitamin D status, bone mineral density and mental health in young Australian women: the Safe-D study. J Public Health Res. 2015; 4(3):594.

55. Maddock J, Berry DJ, Geoffroy MC, Power C, Hyppönen E. Vitamin D and common mental disorders in mid-life: cross-sectional and prospective findings. Clin Nutr. 2013; 32(5):758-64.

56. Maddock J, Geoffroy MC, Power C, Hyppönen E. 25-hydroxyvitamin D and cognitive performance in mid-life. Br J Nutr. 2014; 111(5):904-14.

57. Llewellyn DJ, Langa KM, Lang IA. Serum 25-hydroxyvitamin D concentration and cognitive impairment. J Geriatr Psychiatry Neurol 2009; 22(3):188-95

58. Cherrie MPC, Wheeler BW, White MP, Sarran CE, Osborne NJ. Coastal climate is associated with elevated solar irradiance and higher $25(\mathrm{OH}) \mathrm{D}$ level. Environ Int. 2015; 77:76-84. 